\title{
Impact of electron beam irradiation on the chlorophyll degradation and antioxidant capacity of mango fruit
}

\author{
Truc Trung Nguyen ${ }^{1}$, Apiradee Uthairatanakij ${ }^{1,2}$, Varit Srilaong ${ }^{1,2}$, Natta Laohakunjit ${ }^{3}$, Masaya Kato ${ }^{4}$ \\ and Pongphen Jitareerat ${ }^{1,2^{*}}$
}

\begin{abstract}
At the present, the mechanism of chlorophyll degradation in response to ionizing irradiation in harvested fruits have not been examined. To understand the effect of electron beam (E-beam) irradiation on the chlorophyll degrading pathway in relation to chlorophyll degrading enzymes activity, reactive oxygen species (ROS) and antioxidant capacities of harvested mangoes stored at $13^{\circ} \mathrm{C}$ for 16 days were studied. E-beam-treated fruit significantly suppressed the activities of chlorophyll degrading enzymes especially pheophytinase (PPH) and chlorophyll degrading peroxidase (Chl-POX) in the late stage of storage. This resulted in the chlorophyll content being maintained. However, E-beam irradiation did not affect the activities of chlorophyllase (Chlase) and magnesium de-chelatase (MD). The respiration rate, ethylene production, $\mathrm{ROS}$ accumulation (hydrogen peroxide $\left[\mathrm{H}_{2} \mathrm{O}_{2}\right]$ and superoxide radical $\left[\mathrm{O}^{-} \cdot{ }_{2}\right]$ ) immediately increased after E-beam treatment, following which they significantly decreased in comparison to the control. E-beam treatment enhanced the fruit's antioxidant capacity by activating the activities of catalase (CAT) and ascorbate peroxidase (APX) and glutathione (GSH) content, and inactivated the activity of superoxide dismutase (SOD). Further, it did not affect the activity of glutathione reductase (GR) and glutathione disulfide (GSSG), vitamin C content, or total phenolic content. These results imply that E-beam treatment has the potential to delay chlorophyll degradation by suppressing the ChI-POX and PPH activities as well as reduce ROS production via CAT, APX, and SOD activities and GSH content.
\end{abstract}

Keywords: Ionizing irradiation, Chlorophyll degradation, Reactive oxygen species, Antioxidant capacity

\section{Introduction}

Mango (Mangifera indica L.) is a popular tropical fruit for its dietary fiber, vitamin $\mathrm{C}$, and pigments and is an excellent source of antioxidants and phytochemicals [1-3]. After harvesting, it ripens within 4 days under ambient temperature [4]. One of the most visible changes during the postharvest ripening of mangoes is chlorophyll degradation [5], which further leads to the yellowing of its

\footnotetext{
*Correspondence: pongphen.jit@kmutt.ac.th

${ }^{1}$ Division of Postharvest Technology, School of Bioresources and Technology, King Mongkut's University of Technology Thonburi, Bangkok 10140, Thailand

Full list of author information is available at the end of the article
}

skin quickly. The yellow appearance indicates that mango fruit cannot be stored long periods because it is consequent senescence in shortly. Therefore, the delaying of the chlorophyll degradation is one criteria that help to extend the storage life of mango which it can be exported for long distance markets.

Chlorophyll is a naturally green pigment biosynthesized in higher plants. Chlorophyll is a photochemically active compound that also plays a role in human health [6]. During storage, chlorophyll degradation takes place in two stages: in the early stage, dephytylation and magnesium dechelation take place. Chlase is one of first enzymes in the chlorophyll degradation process and removes the phytol group in chlorophyll a structure to 
obtain chlorophyllide a [7, 8]. Following this, chlorophyllide a releases magnesium ion to form pheophorbide a, which is catalyzed by $\operatorname{MD}[9,10]$. Following this, the late stage consists of the oxygenolytic cleavage of pheophorbide a, reduction of the red chlorophyll catabolite, and modification of the primary fluorescent chlorophyll catabolite. Pheophorbide a oxygenase (PAO) converts pheophorbide a to red chlorophyll catabolites, which is followed by a reduction in the red chlorophyll catabolite induced by red chlorophyll catabolite reductase (RCCR), resulting in a colorless fluorescent product known as the primary fluorescent chlorophyll catabolite. Then, the primary fluorescent chlorophyll catabolite is transformed to fluorescent chlorophyll catabolites via a demethylation and hydroxylation process [11, 12]. Additionally, previous researchers have reported that Chl-POX can convert chlorophyll a to $13^{2}$-hydroxychlorohyll a, which is a fluorescent chlorophyll catabolite, in the presence of $\mathrm{H}_{2} \mathrm{O}_{2}$ and phenolic compounds such as $p$-coumaric acid, apigenin, and 2,4-dichlorophenol [13, 14]. Further, chlorophyll is degraded by the oxidation of its phytyl chain, caused by reactive oxygen species (ROS) or oxy free radicals in higher plants such as Petroselinum sativum [15] and Posidonia oceanica [16].

Ionizing irradiation is a form of non-thermal technology that is widely used to solve various agricultural problems, such as inactivating the food-borne pathogens, suppressing the sprouting of tuber crops, delaying the ripening of harvested produce, and controlling postharvest losses caused by insect and fungal infestations [17]. Ionizing gamma irradiation has been reported to maintain chlorophyll content in quince fruit [18], tomatoes [19], plums [20], pears [21], fenugreek, and spinach [22] whereas ionizing E-beam treatment could reduce postharvest disease, maintain firmness and also delay the color change of mango fruit [23]. However, there is a lack of knowledge about the effect of ionizing E-beam irradiation on chlorophyll-degrading enzymes and the correlation between chlorophyll degradation and ROS production in mangoes. Therefore, the present study is the first report to show that ionizing E-beam irradiation delays chlorophyll degradation by suppressing chlorophyll-degrading enzyme activities and ROS production as well as enhances antioxidant capacity in harvested mangoes.

\section{Materials and methods}

\section{Mango samples and electron beam treatment}

Mature green mangoes cv. Nam Dok Mai Si Thong were harvested from a farm in the Ratchaburi province (90100 days after fruit set) and transported to a research laboratory at the Division of Postharvest Technology within $2 \mathrm{~h}$. The fruits were checked for uniformity in size, weight
(350-370 g), color, and shape, and they were free of any visible defects and infestations. They were surface disinfested with a solution of $0.1 \mathrm{~g} \mathrm{~L}^{-1}$ sodium hypochlorite and airdried for $2 \mathrm{~h}$ before treatment. Our preliminary test showed that E-beam treatments of $>1.0 \mathrm{kGy}$ causes physical injury to the mango peel after $24 \mathrm{~h}$ of treatment, whereas $0.5 \mathrm{kGy}$ causes no injury. Thus, $0.5 \mathrm{kGy}$ E-beam irradiation was chosen for this experiment.

One hundred twenty fruits were placed in a corrugated paper box $(40 \times 20 \times 10 \mathrm{~cm} ; 15$ fruits per box $)$ and treated with $0.5 \mathrm{kGy}$ E-beam at an ambient temperature of $28 \pm 2{ }^{\circ} \mathrm{C}$. The irradiation was carried out at the Thailand Institute of Nuclear Technology (TINT), Nakhon Nayok province. An E-beam linear accelerator (AECL accelerators, Kanata On, Canada) of $10 \mathrm{meV}$ with a pulse repetition frequency (PRF) of $60 \mathrm{~Hz}$ was used, and the under beam conveyor (UBC) speed was controlled at $0.024 \mathrm{~m} \mathrm{~s}^{-1}$ to treat the mangoes. Eight alanine dosimeters (TSS Quotation-SP, Thai Sterilization Services Co. Ltd.) per box were attached to the top and bottom of each fruit's surface to measure the desired dose. The dosimeters were then read using an alanine dosimeter reader (Electron spin resonance spectroscopy) (Additional file 1). None of the fruits exposed to the E-beam (120 fruits) were used as the control.

The dosage uniformity value of the treated fruits $\left(D_{\max } /\right.$ $\mathrm{D}_{\text {min }}$ ) was satisfactory at 1.81 ; the accepted range for the uniformity ratio value of an electron beam is required to be between 1.5 and 2 or even higher [24]. After irradiation, all the fruit samples were stored at $13{ }^{\circ} \mathrm{C}$ for 16 days. The samples were then randomly collected to evaluate the chlorophyll content, activity of chlorophyll-degrading enzymes, ROS, antioxidant capacity, respiration rate, and ethylene production during the initial days and then after 4-day intervals.

\section{Determination of the peel color}

The color changes in the mango peel were measured using a colorimeter (Model CR-400, Konica Minolta, Japan) every 4 days. The colors were determined for three positions of the fruit's surface (upper, middle, and lower parts) and averaged to obtain one value per fruit. The values for $L^{*}, a^{*}, b^{*}$, and hue angle were recorded. The total difference in the color value $(\Delta \mathrm{E}$ is the color change between two measurement times) was calculated using the following formula:

$$
\Delta E=\sqrt{\left(L_{0}^{*}-L_{t}^{*}\right)^{2}+\left(a_{0}^{*}-a_{t}^{*}\right)^{2}+\left(b_{0}^{*}-b_{t}^{*}\right)^{2}}
$$

where $L_{0}^{*}, a_{0}^{*}$, and $b_{0}^{*}$ indicate the color values of the samples on the initial day (day 0 ), and $L_{t}^{*}, a_{t}^{*}$, and $b_{t}^{*}$ indicate the values of the samples every 4 days throughout the storage period. 


\section{Determination of chlorophyll content}

Chlorophyll was extracted with $\mathrm{N}, \mathrm{N}$-dimethylformamide at $4{ }^{\circ} \mathrm{C}$ in the dark for $24 \mathrm{~h}$. The solution was filtered through Whatman No.1 filter paper. The absorption value of the chlorophyll content was measured at 664 and $647 \mathrm{~nm}$ using a spectrophotometer (UV-1800; Shimadzu Co., Kyoto, Japan) and expressed as $\mathrm{mg} \mathrm{kg}^{-1}$ of fresh weight [25].

\section{Substrate preparation of chlorophyll degrading enzymes Acetone powder}

A $5 \mathrm{~g}$ sample of mango peel was homogenized in $100 \mathrm{~mL}$ cold acetone $\left(-20{ }^{\circ} \mathrm{C}\right)$. The homogenate was filtered through filter paper (Whatman No. 1). The residue was washed with cold acetone and ethyl acetate to elute pigments and then completely dried under a vacuum pump at room temperature $\left(25 \pm 2{ }^{\circ} \mathrm{C}\right)$ for $20 \mathrm{~min}$. It was then transferred to a desiccator jar containing silica gel for 1 day and stored at $-20^{\circ} \mathrm{C}[26]$.

\section{Chlorophyll a}

Chlorophyll a was prepared from spinach leaves by following method of Aiamla-Or et al. [27]. Spinach leaves $(5 \mathrm{~g})$ were homogenized for $3 \mathrm{~min}$ in $20 \mathrm{~mL}$ cold acetone $\left(-20^{\circ} \mathrm{C}\right)$. The homogenate was filtered through a filter paper (Whatman No. 1), and the filtrate was treated with 1,4-dioxane and distilled water in the ratio $4: 2: 3(\mathrm{v} / \mathrm{v})$, followed by incubation at $4{ }^{\circ} \mathrm{C}$ in the dark for $1 \mathrm{~h}$. The filtrate was centrifuged at $10,000 \times g$ for 15 min at $4{ }^{\circ} \mathrm{C}$, after which the pellets were dissolved again in the mixture of acetone, 1,4-dioxane, and distilled water $(15: 2: 5 \mathrm{v} / \mathrm{v})$ and kept at $4{ }^{\circ} \mathrm{C}$ in the dark for $1 \mathrm{~h}$. Subsequently, the soluble pellets were centrifuged at $10,000 \times g$ for $15 \mathrm{~min}$ at $4{ }^{\circ} \mathrm{C}$. Afterward, the pellets were dissolved in petroleum ether and stored at $-20{ }^{\circ} \mathrm{C}$ until the individual pigments were separated using sugar powder column chromatography. Finally, $0.5 \mathrm{~g} \mathrm{~L}^{-1}$ of chlorophyll a was prepared in acetone.

\section{Chlorophyllin a}

The solution of chlorophyll a in acetone $\left(0.5 \mathrm{~g} \mathrm{~L}^{-1}\right)$ was deposited into petroleum ether. The chlorophyll a in the petroleum ether phase was washed three times with distilled water to obtain concentrated chlorophyll a. Afterward, chlorophyllin a was precipitated with $30 \%$ potassium hydroxide $(\mathrm{KOH})$ in methanol. Further, the solution was centrifuged at $16,000 \times g$ for $15 \mathrm{~min}$ at $4{ }^{\circ} \mathrm{C}$ and dissolved in distilled water. Subsequently, chlorophyllin a was adjusted to $\mathrm{pH} 9.0$ using $1 \mathrm{M}$ Tricine [28].

\section{Pheophytin a}

Pheophytin a was prepared from chlorophyll a in acetone $\left(0.5 \mathrm{~g} \mathrm{~L}^{-1}\right)$ by adding one drop of $0.1 \mathrm{~N}$ hydrochloric acid $(\mathrm{HCl})$. After treatment for $2 \mathrm{~min}$, the pheophytin a solution was neutralized by $0.1 \mathrm{~N}$ sodium hydroxide $(\mathrm{NaOH})$ until a $\mathrm{pH}$ of 7.0 was reached [29].

\section{Chlorophyll degrading enzyme activity assay}

An extraction of crude enzymes was conducted using $0.5 \mathrm{~g}$ of mango peel acetone powder mixed with $15 \mathrm{~mL}$ of $10 \mathrm{mM}$ phosphate buffer ( $\mathrm{pH} 7.0$ ), containing $0.6 \%$ CHAPS (3-[(3-cholamidopropyl) dimethylammonio]1-propanesulfonate) for Chlase. For Chl-POX, a mango peel acetone powder $(0.5 \mathrm{~g})$ was suspended in $15 \mathrm{~mL}$ of $50 \mathrm{mM}$ phosphate buffer ( $\mathrm{pH}$ 7.0). In the case of $\mathrm{PPH}$, a $50 \mathrm{mM}$ Tris- $\mathrm{HCl}$ (Tris (hydroxymethyl) aminomethane-hydrochloric acid) buffer ( $\mathrm{pH}$ 8.0) was used instead of $50 \mathrm{mM}$ phosphate buffer ( $\mathrm{pH}$ 7.0). For MD, a mango peel acetone powder $(0.5 \mathrm{~g})$ was assorted with $15 \mathrm{~mL}$ of $10 \mathrm{mM}$ phosphate buffer ( $\mathrm{pH} 7.0$ ) containing $50 \mathrm{mM}$ potassium chloride $(\mathrm{KCl})$ and $0.24 \%$ Triton-X 100. The mixture solutions were stirred at $4{ }^{\circ} \mathrm{C}$ for $1 \mathrm{~h}$ and filtered with two layers of Miracloth. The filtrate was then centrifuged at $16,000 \times g$ at $4{ }^{\circ} \mathrm{C}$ for $15 \mathrm{~min}$. The supernatant was used as the crude enzyme extract. The protein content of the crude extract was determined following Bradford's method [30].

\section{Chlase activity}

Chlase activity was analyzed following the AiamlaOr et al.s method [26]. The reaction mixture contained $0.5 \mathrm{~mL}$ of $0.1 \mathrm{mM}$ phosphate buffer $(\mathrm{pH} 7.5), 0.2 \mathrm{~mL}$ of $0.5 \mathrm{~g} \mathrm{~L}^{-1}$ chlorophyll a in acetone solution, and $0.5 \mathrm{~mL}$ of crude enzyme solution. The reaction mixture was incubated at room temperature $\left(25 \pm 2{ }^{\circ} \mathrm{C}\right)$ for $60 \mathrm{~min}$, and the enzyme reaction was inhibited by adding $4 \mathrm{~mL}$ of acetone. Chlorophyllide a was separated by adding $4 \mathrm{~mL}$ of hexane. The upper phase contained the remaining chlorophyll a, while the lower phase contained chlorophyllide a. The activity was spectrophotometrically detected by the formation of chlorophyllide a at $667 \mathrm{~nm}$ $\left(76.79 \mathrm{mM}^{-1} \mathrm{~cm}^{-1}\right)$ per min per $\mathrm{mg}$ of protein.

\section{Chl-POX activity}

Chl-POX activity was measured in accordance with Yamauchi et al. [31] but with some modifications. The reaction mixture contained $0.5 \mathrm{~mL}$ of crude enzyme extract, $0.1 \mathrm{~mL}$ of $1.0 \%$ Triton-X 100, $0.1 \mathrm{~mL}$ of $5 \mathrm{mM}$ $p$-coumaric acid, $0.2 \mathrm{~mL}$ of $0.5 \mathrm{~g} \mathrm{~L}^{-1}$ chlorophyll a in acetone solution, $1.5 \mathrm{~mL}$ of $0.1 \mathrm{mM}$ phosphate buffer $(\mathrm{pH}$ 5.5 ), and $0.1 \mathrm{~mL}$ of $0.3 \%$ hydrogen peroxide. The reaction mixture was incubated at $25 \pm 2{ }^{\circ} \mathrm{C}$ for $40 \mathrm{~min}$. Enzyme activity was spectrophotometrically determined by measuring the decrease in chlorophyll a at $668 \mathrm{~nm}$ per min per mg of protein at $25 \pm 2{ }^{\circ} \mathrm{C}$. 


\section{PPH activity}

PPH activity was determined by using the method given by Kaewsuksaeng et al. [29]. The reaction mixture contained $0.5 \mathrm{~mL}$ of $50 \mathrm{mM}$ Tris- $\mathrm{HCl}$ buffer $(\mathrm{pH} 8.0)$, $0.25 \mathrm{~mL}$ of pheophytin a $\left(0.043 \mathrm{~g} \mathrm{~L}^{-1}\right)$ in acetone solution, and $0.25 \mathrm{~mL}$ of crude enzyme extract. The mixture was incubated at $25 \pm 2{ }^{\circ} \mathrm{C}$ for $40 \mathrm{~min}$ and then inhibited by adding $2 \mathrm{~mL}$ of acetone. The PPH activity was spectrophotometrically detected based on the pheophorbide a formation at $665 \mathrm{~nm}\left(44 \mathrm{mM}^{-1} \mathrm{~cm}^{-1}\right)$ per min per mg of protein.

\section{MD activity}

MD activity was spectrophotometrically determined using chlorophyllin a by measuring the absorbance of pheophorbin a formation at $686 \mathrm{~nm}$ [32]. The reaction mixture, which contained $0.5 \mathrm{~mL}$ of $50 \mathrm{mM}$ Tris-tricine buffer ( $\mathrm{pH} 8.8), 0.1 \mathrm{~mL}$ of chlorophyllin a $\left(\mathrm{OD}_{687}=0.4\right)$, and $0.2 \mathrm{~mL}$ of crude enzyme extract, was incubated at $37{ }^{\circ} \mathrm{C}$ for $3 \mathrm{~min}$. MD activity was expressed as the increment of OD at $686 \mathrm{~nm}$ per min per mg of protein under the test conditions.

\section{Ethylene production and respiration rate}

One fruit was incubated in plastic box (1.4 L in volume) for $3 \mathrm{~h}$ at $13{ }^{\circ} \mathrm{C}$. One milliliter of gas sample from the headspace of the plastic box was drawn using a syringe and injected into a gas chromatograph (Shimadzu GC14B, Bara scientific, Japan) with a thermo-conductivity detector for carbon dioxide analysis and a flame ionization detector for ethylene analysis. Each treatment consisted four replicates (boxes).

\section{Hydrogen peroxide and superoxide radical}

The hydrogen peroxide $\left(\mathrm{H}_{2} \mathrm{O}_{2}\right)$ content was measured using Wu et al's method [33], albeit with some modifications. Peel fruit tissue $(0.5 \mathrm{~g})$ was mixed with $8 \mathrm{~mL}$ of $5 \%$ cold trichloroacetic acid (w/v) and was subsequently homogenized and centrifuged at $10,000 \times g$ at $4{ }^{\circ} \mathrm{C}$ for $10 \mathrm{~min}$. The reaction mixture was prepared using $0.5 \mathrm{~mL}$ of the supernatant, $4 \mathrm{~mL}$ of $5 \%$ trichloroacetic, and $0.5 \mathrm{~mL}$ of assay reagent containing $500 \mu \mathrm{M}$ ferrous ammonium sulfate, $50 \mathrm{mM}$ sulfuric acid $\left(\mathrm{H}_{2} \mathrm{SO}_{4}\right), 200 \mu \mathrm{M}$ xylenol orange, and $200 \mathrm{mM}$ sorbitol. The reaction mixture was incubated at $25 \pm 2{ }^{\circ} \mathrm{C}$ for $45 \mathrm{~min}$. During the incubation period, the hydrogen peroxide molecule oxidized $\mathrm{Fe}^{2+}$ to $\mathrm{Fe}^{3+}$ ion, which was determined by measuring the absorbance of the ferric-xylenol orange complex at $560 \mathrm{~nm}$. The absorbance values were calibrated to a standard curve, generated using the known concentrations of $\mathrm{H}_{2} \mathrm{O}_{2}$.

The production rate of superoxide radical $\left(\mathrm{O}^{-}{ }_{2}\right)$ was analyzed using the method given by Elstner and Heupel [34]. Peel tissue samples (1 g) were homogenized with
$8 \mathrm{~mL}$ of $65 \mathrm{mM}$ phosphate buffer ( $\mathrm{pH} 7.8)$ containing $1 \mathrm{mM}$ ethylenediaminetetraacetic acid (EDTA), 1\% polyvinylpolypyrrolidone (PVPP w/v), and 0.3\% Triton X-100. The extraction mixture was centrifuged at $5000 \times g$ for $15 \mathrm{~min}$ at $4{ }^{\circ} \mathrm{C}$. After centrifugation, $0.5 \mathrm{~mL}$ of the supernatant was mixed with $1 \mathrm{~mL}$ of $50 \mathrm{mM}$ phosphate buffer (pH 7.8) and $0.5 \mathrm{~mL}$ of $10 \mathrm{mM}$ hydroxylamine hydrochloride and subsequently incubated at $25 \pm 2{ }^{\circ} \mathrm{C}$ for $20 \mathrm{~min}$ in dark conditions. A $1 \mathrm{~mL}$ sample of the above reaction mixture was added to $1 \mathrm{~mL}$ of $19 \mathrm{mM}$-aminobenzene sulfonic acid and $1 \mathrm{~mL}$ of $7 \mathrm{mM} \alpha$-naphthylamine to formulate a new mixture, which was then incubated at $25 \pm 2{ }^{\circ} \mathrm{C}$ for $20 \mathrm{~min}$ in dark conditions. The $\mathrm{O}^{-}{ }_{2}$ content was calculated based on a comparison of absorbance with a standard curve (using sodium nitrite as the standard) at $530 \mathrm{~nm}$. The $\mathrm{O}^{-}{ }_{2}$ production rate was expressed as $\mu \mathrm{mol}$ $\mathrm{NO}_{2} \mathrm{~kg}^{-1} \mathrm{~s}^{-1}$ of fresh weight.

\section{Antioxidant compounds and enzymatic antioxidant activities GSH and GSSG assay}

Crude extracts for the analysis of total glutathione were prepared by homogenizing $2 \mathrm{~g}$ of mango peel in $10 \mathrm{~mL}$ of cold $0.9 \% \mathrm{NaCl}(\mathrm{w} / \mathrm{v})$ containing $5 \mathrm{mM}$ EDTA, which was then centrifuged at $17,000 \times g$ at $4{ }^{\circ} \mathrm{C}$ for $10 \mathrm{~min}$. For $\mathrm{GSH}$, $5 \mathrm{~mL}$ of the above crude extract was precipitated with $5 \mathrm{~mL}$ of cold $30 \%$ trichloroacetic acid (w/v) for $5 \mathrm{~min}$. Further, it was centrifuged at $17,000 \times g$ at $4{ }^{\circ} \mathrm{C}$ for $10 \mathrm{~min}$ to remove protein [35]. The total and GSH contents were measured using the method stated by Griffth [36] but with some modifications. The reaction to determine the total glutathione content was facilitated by mixing $1.4 \mathrm{~mL}$ of $0.3 \mathrm{mM}$ nicotinamide adenine dinucleotide phosphate (NADPH) and $200 \mu \mathrm{L}$ of $6 \mathrm{mM}$ DTNB (Ellman's reagent; $5,5^{\prime}$-dithiobis-(2-nitrobenzoic acid)) in $100 \mathrm{mM}$ phosphate buffer with $5 \mathrm{mM}$ EDTA disodium salt $(\mathrm{pH} 7.5)$, $0.02 \mathrm{~mL}$ of glutathione reductase $\left(50 \mathrm{U} \mathrm{mg}^{-1}\right.$ protein from yeast), and $0.4 \mathrm{~mL}$ of crude extract. The GSH content was measured using $0.2 \mathrm{~mL}$ of $6 \mathrm{mM}$ DTNB, $1.4 \mathrm{~mL}$ of $100 \mathrm{mM}$ phosphate buffer with $5 \mathrm{mM}$ EDTA disodium

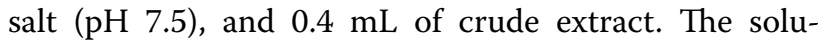
tion of total glutathione and GSH assay was incubated at $25 \pm 2{ }^{\circ} \mathrm{C}$ for $1 \mathrm{~h}$ and subsequently measured using a spectrophotometer at $412 \mathrm{~nm}$. The GSSG content was calculated using total glutathione subtract to the content of GSH in a similar sample. The GSH and GSSG contents were calculated using a standard graph and expressed in terms of milligrams of glutathione equivalents per kilogram of fresh weight.

\section{Total phenolic content}

The crude extract was prepared following the method given by Ribeiro et al. [37] but with some 
modifications. $2.5 \mathrm{~g}$ of mango peel was mixed with $10 \mathrm{~mL}$ of methanol:water $(60: 40 \mathrm{v} / \mathrm{v})$. The sample was homogenized and then centrifuged at $15,000 \times g$ for $20 \mathrm{~min}$ at $4{ }^{\circ} \mathrm{C}$. The supernatant was used to determine the total phenolic content using the Folin-Ciocalteu method, as described by Singleton et al. [38]. For the reaction mixture, aliquot of $0.05 \mathrm{~mL}$ of the extract was added to $0.25 \mathrm{~mL}$ of Folin-Ciocalteu reagent, followed by an addition of $0.75 \mathrm{~mL}$ of $7.5 \%$ sodium carbonate solution and $2 \mathrm{~mL}$ of distilled water. The mixture was vortexed and incubated in a water bath at $40{ }^{\circ} \mathrm{C}$ for $30 \mathrm{~min}$. The absorbance was measured at a wavelength of $750 \mathrm{~nm}$ using a spectrophotometer (UV 1800, Shimadzu, Kyoto, Japan). A blank sample consisting of distilled water and the Folin-Ciocalteu reagent was used for comparison purposes. The results were expressed in terms of grams of gallic acid equivalents (GAE) per kilogram of fresh weight.

\section{Vitamin C content}

Vitamin C content was measured following Roe et al's method [39]. Five grams of mango peel were homogenized with $20 \mathrm{~mL}$ of cold $5 \%$ metaphosphoric acid and then filtered through Whatman No. 1 filter paper. Aliquot of the filtrate was centrifuged at $17,000 \times \mathrm{g}$ for $20 \mathrm{~min}$ at $4{ }^{\circ} \mathrm{C}$. The reaction mixture was prepared using $0.4 \mathrm{~mL}$ of filtrated solution and $0.2 \mathrm{~mL}$ of $0.02 \%$ di-indophenol. This was added to $0.4 \mathrm{~mL}$ of $2 \%$ thiourea and $0.2 \mathrm{~mL}$ of $2 \%$ dinitrophenol hydrazine and then incubated at $50{ }^{\circ} \mathrm{C}$ for $1 \mathrm{~h}$. After incubation, $1 \mathrm{~mL}$ of $85 \%$ sulfuric acid was added, and the reaction mixture was incubated at an ambient temperature for $30 \mathrm{~min}$. The absorbacne of vitamin C was measured at $540 \mathrm{~nm}$ using a spectrophotometer (UV-1800; Shimadzu Co., Kyoto, Japan) and expressed as $\mathrm{g} \mathrm{kg}^{-1}$ of fresh weight.

\section{SOD activity}

The crude enzymes were extracted using $2 \mathrm{~g}$ of peel tissue in $10 \mathrm{~mL}$ of $65 \mathrm{mM}$ phosphate buffer ( $\mathrm{pH} 7.8$ ) containing $1 \%$ polyvinyl pyrrolidine and $1 \mathrm{mM}$ EDTA. They were then homogenized and centrifuged at $15,000 \times g$ at $4{ }^{\circ} \mathrm{C}$ for $20 \mathrm{~min}$. The enzyme activity was determined according to the indirect spectrophotometric method given by Elstner and Heupel [34]. The reaction mixture contained $0.5 \mathrm{~mL}$ of $65 \mathrm{mM}$ phosphate buffer ( $\mathrm{pH} 7.8$ ) and $1 \mathrm{~mL}$ of xanthine oxidase from bovine milk containing $150 \mu \mathrm{g}$ protein, $0.1 \mathrm{~mL}$ of $1.5 \mu \mathrm{mol}$ xanthine, $0.1 \mathrm{~mL}$ of $1 \mu \mathrm{mol}$ hydroxylamine hydrochloride, and $0.3 \mathrm{~mL}$ of crude enzyme. Following this, the mixture was incubated at $25 \pm 2{ }^{\circ} \mathrm{C}$ for $20 \mathrm{~min}$ in the dark. $0.5 \mathrm{~mL}$ of the above reaction mixture was removed and added to $0.5 \mathrm{~mL}$ of $19 \mathrm{mM} p$-aminobenzene sulfonic acid and $0.5 \mathrm{~mL}$ of $7 \mathrm{mM} \alpha$-naphthylamine to obtain a new mixture, which was then incubated at $25 \pm 2{ }^{\circ} \mathrm{C}$ for $20 \mathrm{~min}$ in the dark. SOD activity was determined by measuring the absorbance of the reaction mixture at a wavelength of $530 \mathrm{~nm}$. One unit of SOD was defined as the enzyme amount that inhibited the nitrite dioxide formation rate by $50 \%$ per min per mg of protein.

\section{CAT and APX activities}

The crude enzymes were extracted adding $2 \mathrm{~g}$ of peel tissue to $10 \mathrm{~mL}$ of $100 \mathrm{mM}$ phosphate buffer (pH 7.5) containing $1 \%$ polyvinyl pyrrolidine and $1 \mathrm{mM}$ EDTA, which was subsequently homogenized and centrifuged at $15,000 \times g$ at $4{ }^{\circ} \mathrm{C}$ for $20 \mathrm{~min}$. The supernatant was used to determine the CAT and APX activity [40].

CAT activity was determined based on the decreasing concentration of $\mathrm{H}_{2} \mathrm{O}_{2}$ (extinction coefficient $39.4 \mathrm{M}^{-1} \mathrm{~cm}^{-1}$ ) at a wavelength of $240 \mathrm{~nm}$ for $90 \mathrm{~s}$. The reaction mixture contained $0.02 \mathrm{~mL}$ of $30 \% \mathrm{H}_{2} \mathrm{O}_{2}$, $0.78 \mathrm{~mL}$ of $100 \mathrm{mM}$ phosphate buffer added to $1 \mathrm{mM}$ EDTA (pH 7.5), and $0.2 \mathrm{~mL}$ of crude extract enzyme.

APX activity was measured based on the oxidation of ascorbate by $\mathrm{H}_{2} \mathrm{O}_{2}$ (extinction coefficient $2800 \mathrm{M}^{-1} \mathrm{~cm}^{-1}$ ) at a wavelength of $290 \mathrm{~nm}$ for $90 \mathrm{~s}$. The reaction mixture contained $0.05 \mathrm{~mL}$ of enzyme extract, $0.05 \mathrm{~mL}$ of $10 \mathrm{mM}$ ascorbate, and $0.89 \mathrm{~mL}$ of $0.1 \mathrm{M}$ phosphate buffer, to which $1 \mathrm{mM}$ EDTA ( $\mathrm{pH} 7.5$ ) was added. The reaction was initiated by adding $0.01 \mathrm{~mL}$ of $20 \mathrm{mM}$ $\mathrm{H}_{2} \mathrm{O}_{2}$.

\section{GR activity}

A $2 \mathrm{~g}$ sample of peel tissue was homogenized with $10 \mathrm{~mL}$ of $50 \mathrm{mM}$ phosphate buffer (pH 7.0) containing $0.1 \mathrm{mM}$ EDTA. The homogenate was centrifuged at $17,000 \times g$ for $10 \mathrm{~min}$ at $4{ }^{\circ} \mathrm{C}$. The supernatant was collected and used for the enzyme assays. The GR activity was determined based on the oxidation of NADPH (extinction coefficient $6200 \mathrm{M}^{-1} \mathrm{~cm}^{-1}$ ) at $340 \mathrm{~nm}$ for $1 \mathrm{~min}$, as described by Rao et al. [41]. The reaction mixture $(2 \mathrm{~mL})$ was obtained by mixing $1.6 \mathrm{~mL}$ of $100 \mathrm{mM}$ phosphate buffer ( $\mathrm{pH} 7.8)$ containing $2 \mathrm{mM}$ EDTA, $0.2 \mathrm{mM}$ NADPH, $0.5 \mathrm{mM}$ GSSG, and $0.4 \mathrm{~mL}$ of the enzyme supernatant.

\section{Statistical analysis}

The obtained data were analyzed using the general linear model procedure with the statistical analysis software (SAS), version 9.0 (SAS Institute, Cary, N.C., USA), for completely randomized design experiments. The means were compared using an independent samples $\mathrm{t}$-test. The value of $\mathrm{P}<0.05, \mathrm{P}<0.01$, and $\mathrm{P}<0.001$ expressed the statistical significance. Each treatment consisted 3 replications and each replication consisted 6 fruits. Color measurement, the color values from 6 fruits were averaged and presented as the mean of one replication. 
Biochemical analysis, the equal amounts of tissue samples from 6 fruits were collected, mixed well and used as one replication to assay the chlorophyll contents, chlorophyll-degrading enzyme activities, reactive oxygen species, antioxidant compounds, and enzymatic antioxidant activities. Four replications were used to assay the respiration rate and ethylene production for each treatment. The data were expressed in the form of mean \pm standard error.

\section{Results}

\section{Effect of E-beam irradiation on chlorophyll content} and chlorophyll-degrading enzymes

Chlorophyll is the green pigment that plays a role as an indicator of fresh and healthy fruit. Chlorophyll $a$ and $b$ contents tended to reduce in E-beam-treated fruit and non-treated fruit throughout the storage period. On day 0 , there was no significant difference in chlorophyll a and $\mathrm{b}$ contents of the mango peels in both the treatments. On day 4 of storage, the E-beam treatment stimulated chlorophyll degradation; afterwards the degradation of chlorophyll contents in the E-beam-treated fruit was lower than that of the non-treated fruit from day 8 until the end of the storage period (Fig. 1a, b). This result correlated with the change in color of the peel. A statistical analysis demonstrated that the E-beam-treated fruit had significantly lower values of $\mathrm{a}^{*}$ (greenness) and $\Delta \mathrm{E}$ (total difference in color) than the control fruit from days 8 to 16 (Fig. 2a-f). Thus, E-beam treatment could maintain the green color of the mango peel.

No significant difference in Chlase activity was observed between the control and E-beam-treated fruit throughout the period of storage, and their activity levels were $0.76-1.32 \mathrm{U} \mathrm{mg}^{-1}$ protein (Fig. 1c). The PPH activities of the treated and non-treated fruit were not significantly different from days 0 to 12 , with a range of 2.81-5.33 $\mathrm{U} \mathrm{mg}^{-1}$ protein. However, on the last day (day 16), the PPH activity of the E-beam-treated fruit was 2.12-fold lower than that of the control fruit (Fig. 1d), which is a considerable difference. The Chl-POX activity of the control fruit increased from $0.13 \mathrm{U} \mathrm{mg}^{-1}$ protein on day 0 to $1.19 \mathrm{U} \mathrm{mg}^{-1}$ protein on day 16 , whereas the Chl-POX activity of the E-beam-treated fruit rapidly increased and peaked on day $4\left(0.92 \mathrm{U} \mathrm{mg}^{-1}\right.$ protein) before declining slightly until the end of storage (0.68 $\mathrm{U} \mathrm{mg}^{-1}$ protein). This result indicates that the ChlPOX activity of treated fruit was significantly lower than the control fruit in the late period of storage (Fig. 1f). The MD activity range was $0.47-0.51 \mathrm{U} \mathrm{mg}^{-1}$ protein, and it was not significantly different for the two treatments from days 0 to 12 . However, at the end of the storage period, E-beam-treated fruits showed significantly higher MD activity than the control (Fig. 1e). Thus, the present work demonstrates that the delay in chlorophyll degradation in the mango peel was caused by the E-beam treatment, which suppressed PPH and Chl-POX activities in the later stage of storage. However, E-beam treatment did not strongly affect Chlase and MD activities.

\section{Effect of E-beam irradiation on ethylene production and respiratory rate}

Notably, ethylene production increased immediately after the fruit was treated with E-beam (day 0), and it was significantly higher than that in the non-treated fruit. On days 4 to 12 , ethylene production of the treated and nontreated fruit were not significantly different and remained stable within the range of $1.14-8.50 \mathrm{ng} \mathrm{kg}^{-1} \mathrm{~s}^{-1}$. Moreover, on day 16, the ethylene production in both fruit groups increased; the control fruit showed a rapid increase than the treated fruit (Fig. 3a). E-beam treatment increased the respiration rate by about 1.61 -fold as compared to the non-treated fruits on day 0. After 8-16 days, the respiration rate of E-beam-treated fruit sharply decreased and became lower than that of the control (Fig. 3b).

The present results imply that the E-beam treatment triggered the ethylene production and respiration rate of mangoes in the early stage, which were later suppressed by the treatment.

\section{Effect of E-beam on ROS production}

E-beam treatment induced the production of $\mathrm{O}^{-}{ }_{2}$ immediately after implementation $\left(0.30 \mu \mathrm{mol} \mathrm{kg}^{-1} \mathrm{~s}^{-1}\right)$, which then declined during storage $\left(0.19 \mu \mathrm{mol} \mathrm{kg}^{-1} \mathrm{~s}^{-1}\right)$. In contrast, the $\mathrm{O}^{-}{ }_{2}$ production in the control fruit increased throughout the period of storage (from 0.19 to $0.50 \mu \mathrm{mol} \mathrm{kg}{ }^{-1} \mathrm{~s}^{-1}$ ). At the end of the storage period (day 16), $\mathrm{O}^{-}{ }_{2}$ production in E-beam-treated fruit was approximately 2.6 times lower than that of the control fruit (Fig. 4a). E-beam also induced $\mathrm{H}_{2} \mathrm{O}_{2}$ content immediately after treatment: it was $0.36 \mathrm{mmol} \mathrm{kg}-1$ on day 0 , which was significantly higher than the control fruit $\left(0.19 \mathrm{mmol} \mathrm{kg} \mathrm{kg}^{-1}\right)$. After this, a slight decline occurred until the end of the storage period $\left(0.15 \mathrm{mmol} \mathrm{kg}^{-1}\right)$. In contrast, the $\mathrm{H}_{2} \mathrm{O}_{2}$ content in untreated fruits tended to increase throughout the storage period. On day 16, the $\mathrm{H}_{2} \mathrm{O}_{2}$ content of the control fruit was 2.8-fold higher than that of the treated fruit (Fig. 4b). The results show that the E-beam treatment suppressed $\mathrm{O}^{-}{ }_{2}$ production and $\mathrm{H}_{2} \mathrm{O}_{2}$ content in mango fruit during the storage period.

\section{Effect of E-beam on antioxidant capacity}

The SOD activity in both the treated and control fruits tended to decline during storage. E-beam-treated fruits showed significant suppression in SOD activity from days 0 to 8 as compared to the control, while no significant 

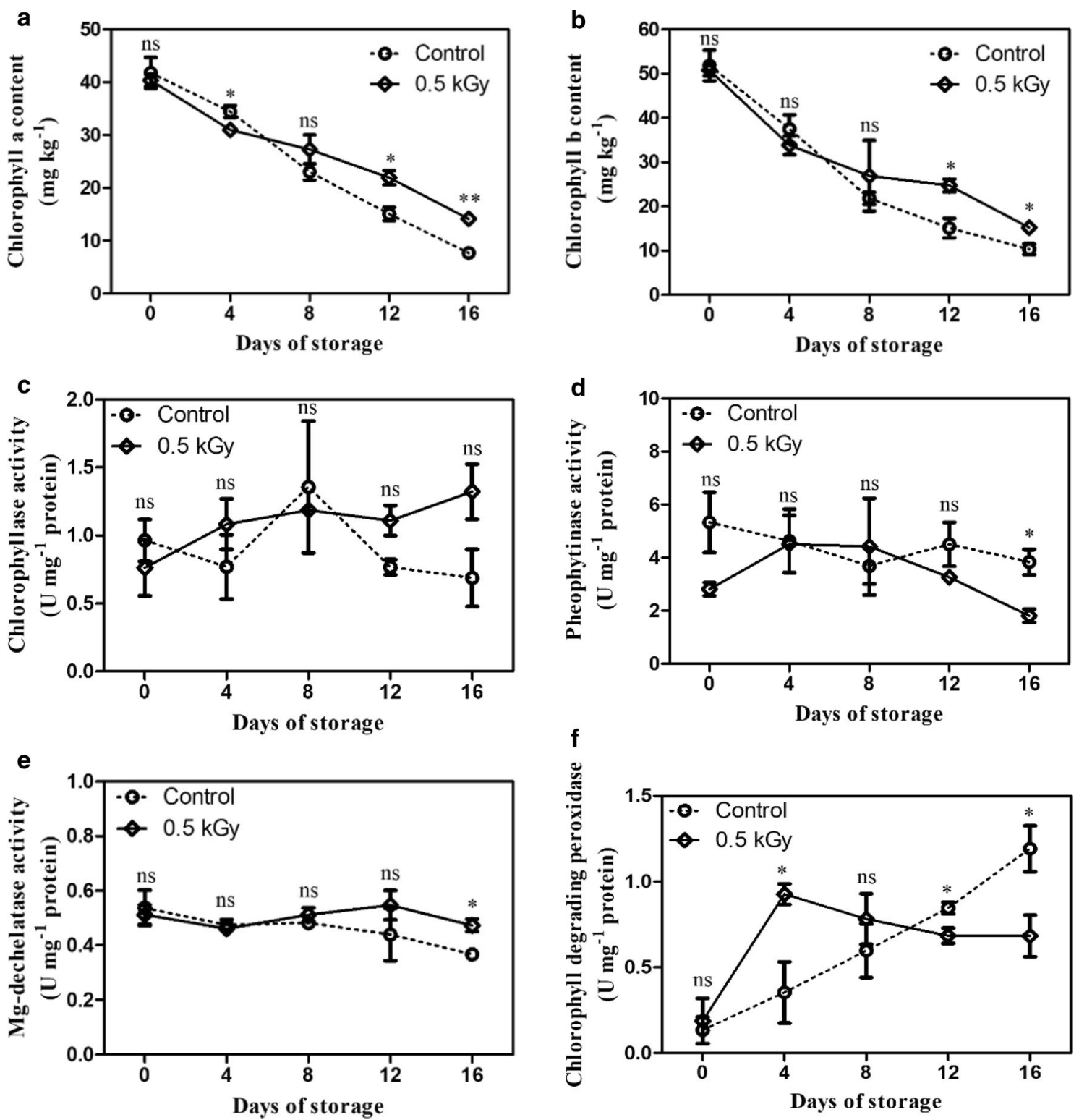

Fig. 1 Chlorophyll a (a) and chlorophyll b (b) contents and chlorophyll degrading enzyme activities: chlorophyllase (c), pheophytinase (d), Mg-dechelatase (e) and chlorophyll degrading peroxidase (f) of mangoes after being treated with E-beam at a dose of 0 (control) and $0.5 \mathrm{kGy}$, and then stored at $13^{\circ} \mathrm{C}$ for 16 days. The data are expressed as mean \pm standard error. Asterisks $\left(^{*}\right)$ indicate significant differences between the two treatments during storage (t-test; ${ }^{*} \mathrm{P}<0.05,{ }^{* *} \mathrm{P}<0.01$, ns not significant)

differences were found on days 12 to 16 (Fig. 5a). CAT activity of both the treatments tended to decrease, and the E-beam-treated fruit had significantly higher CAT activity than the control fruit throughout the storage period except for the first and last few days (Fig. 5b). APX activities of both the treatment and control groups tended to increase during days $0-12$ and peaked on day 12. They declined by the end of storage (day 16). E-beamtreated fruit had significantly higher APX activity on day 0 than the control fruit, followed by an insignificant difference between the E-beam-treated fruit and nontreated fruit until the end of storage (Fig. 5c). The GR activity tended to decrease in both the groups. E-beamtreated fruit had lower GR activity than untreated fruit but without any significant difference during the storage period (Fig. 5d).

The GSH content of the E-beam-treated fruit and control fruit increased from days 0 to 12 and then declined 

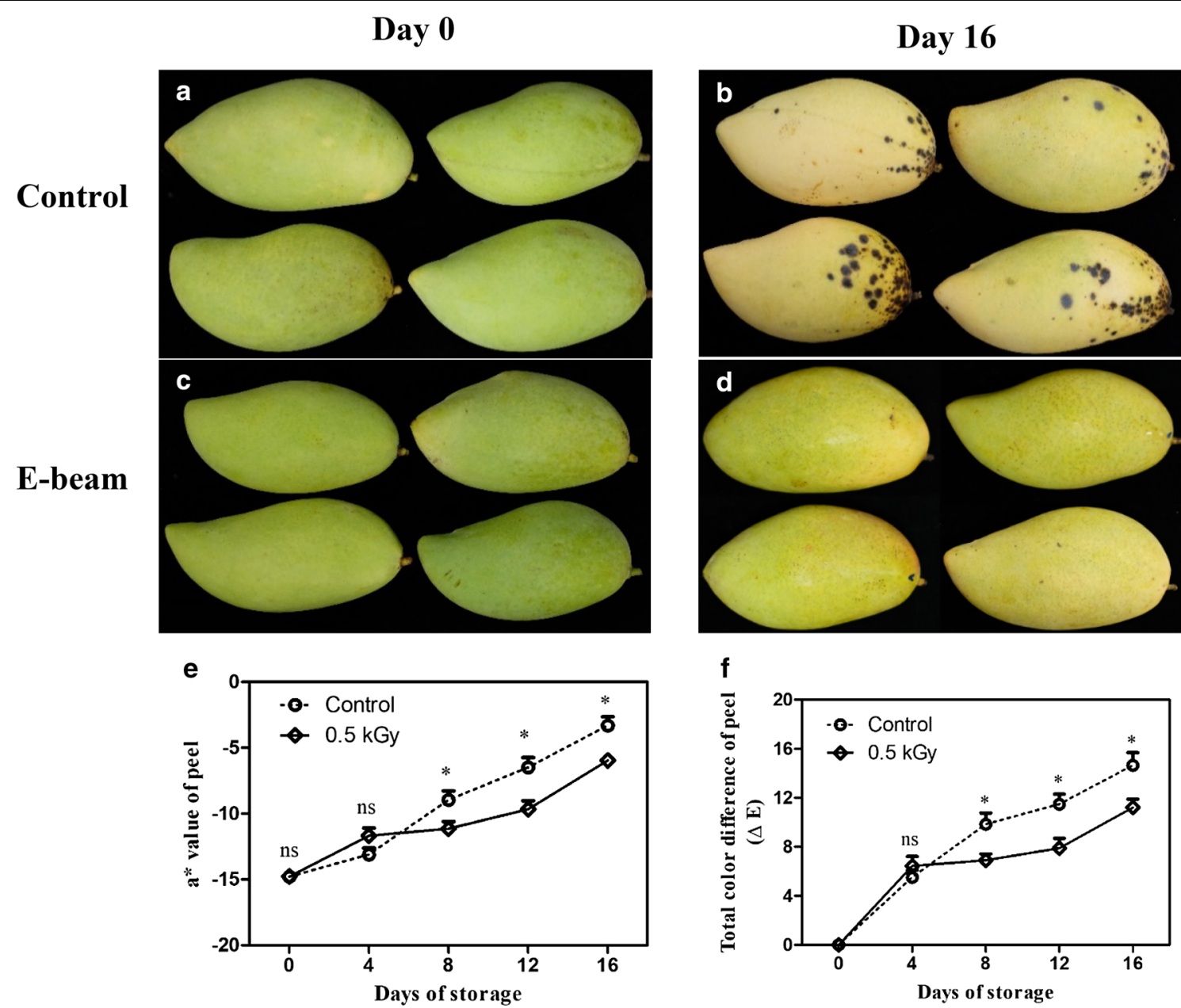

Fig. 2 The appearance of mangoes $(\mathbf{a}-\mathbf{d})$, $\mathrm{a}^{*}$ value (e), and total color difference $(\mathbf{f})$ after treatment with E-beam at a dose of 0 (control) and $0.5 \mathrm{kGy}$, and then stored at $13^{\circ} \mathrm{C}$ for 16 days. The data are expressed as mean \pm standard error. Asterisks $(*)$ indicate significant differences between the two treatments during storage (t-test; ${ }^{*} \mathrm{P}<0.05,{ }^{* *} \mathrm{P}<0.01$, ns not significant)
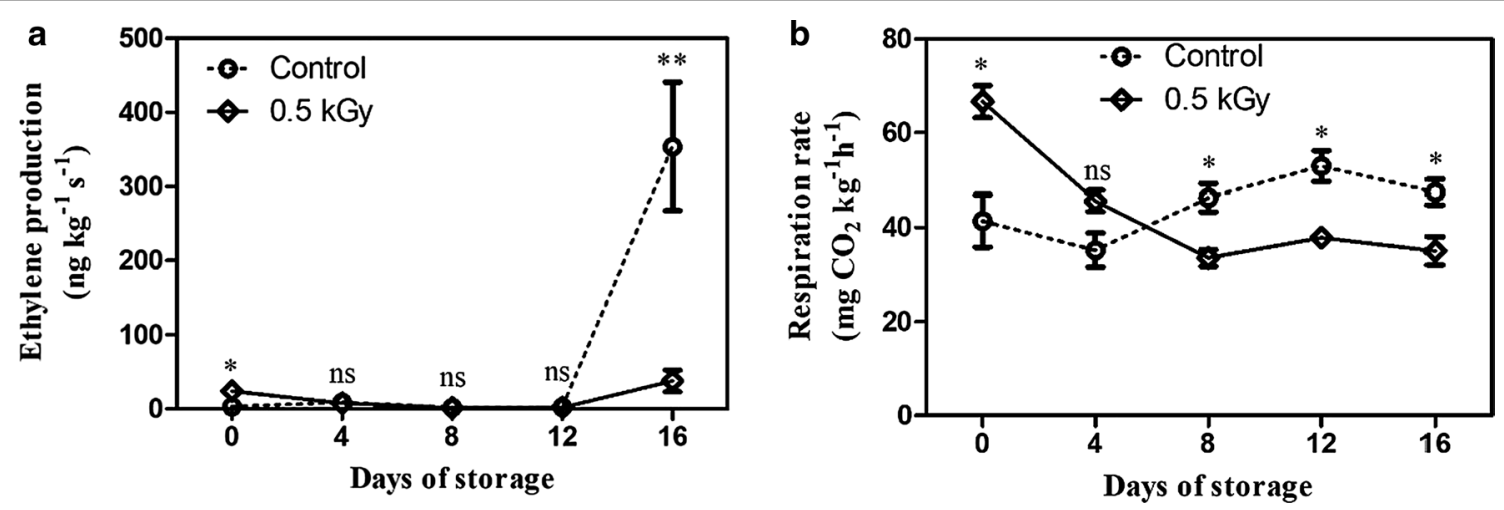

Fig. 3 Ethylene production (a) and respiratory rate (b) of mango fruit after treatment with E-beam at a dose of 0 (control) and $0.5 \mathrm{kGy}$, and then stored at $13^{\circ} \mathrm{C}$ for 16 days. The data are expressed as mean \pm standard error. Asterisks $\left(^{*}\right)$ indicate significant differences between the two treatments during storage (t-test; ${ }^{*} \mathrm{P}<0.05,{ }^{*} \mathrm{P}<0.01$, ns not significant) 

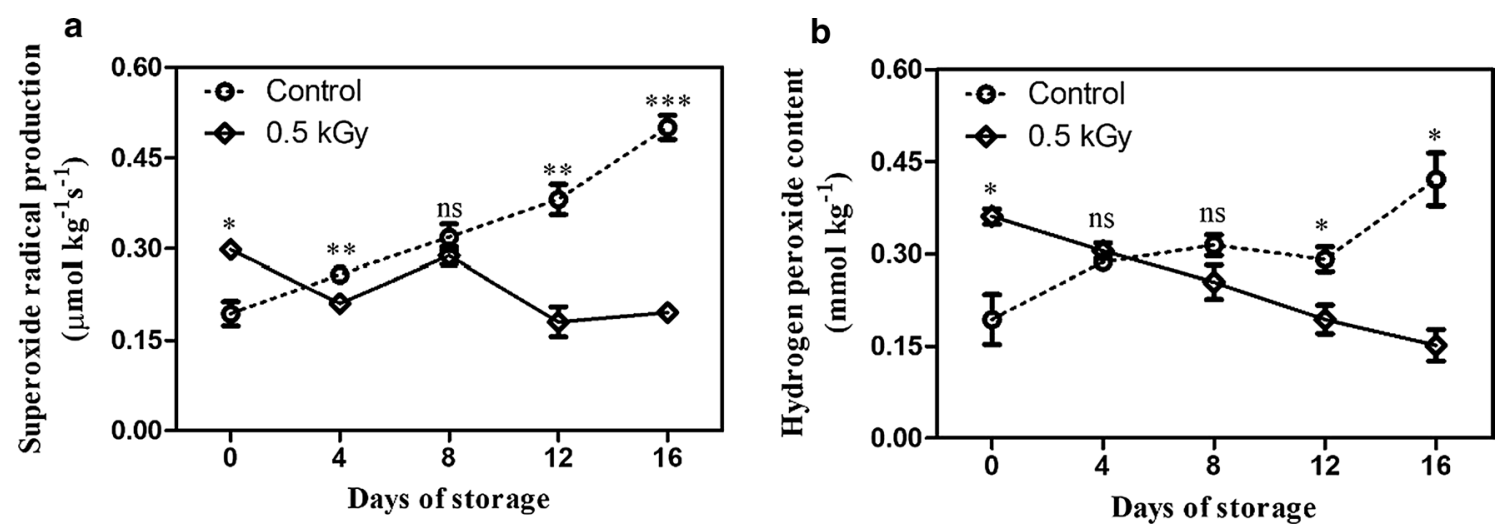

Fig. 4 Superoxide radical (a) and hydrogen peroxide (b) contents of mango after treatment with E-beam at a dose of 0 (control) and $0.5 \mathrm{kGy}$, and then stored at $13{ }^{\circ} \mathrm{C}$ for 16 days. The data are expressed as mean \pm standard error. Asterisks (*) indicate significant differences between the two treatments during storage (t-test; ${ }^{*} \mathrm{P}<0.05,{ }^{* *} \mathrm{P}<0.01,{ }^{* * *} \mathrm{P}<0.001$, ns not significant)

slightly by the end of the storage. The GSH content in the E-beam-treated fruit was significantly higher than that of the control fruit (Fig. 5e). The difference between the GSSG content of the E-beam-treated and control fruit was insignificant from day 0 to 12 . On the last day of storage, the GSSG content of the E-beam-treated fruit was significantly lower than that of the control fruit (Fig. 5f). In the present study, vitamin $\mathrm{C}$ was found to slightly decrease in both the groups, but it was not a significant difference except on day 8 (Fig. $5 \mathrm{~g}$ ). The pattern of phenolic content was similar to the vitamin $C$ content. The phenolic content of the treated fruit and control slightly decreased, and there were no significant differences (Fig. 5h).

\section{Discussion}

The color of a mango is an important and valid criterion to assess its quality, and it plays a crucial role in consumer acceptability. After mangoes are harvested, several biochemical changes are involved in the ripening process, such as an increase in the respiratory rate, ethylene production, and fruit softening as well as pigment changes. Medlicott et al. [42] reported that the mango peel color changes from green to yellow while ripening, which is accompanied by a chlorophyll breakdown. The present research shows that E-beam induces chlorophylldegrading enzyme activity, particularly that of Chl-POX, in the early stages (day 4 ), which then sharply decreases until the end of storage. The Chl-POX activity was significantly lower in the treated fruits than the non-treated fruits. In addition, E-beam irradiation was found to reduce the activity of $\mathrm{PPH}$ and significantly increase MD at the end of the storage. However, in this study, E-beam had no effect on Chlase activity, implying that E-beam irradiation may delay chlorophyll degradation via the suppression of Chl-POX and PPH activities at the end of storage. Previous researches have shown that ionizing gamma irradiation maintains chlorophyll content in quince fruit [18], tomatoes [19], plums [20], and pears [21]. This may be caused by the effect of irradiation on chlorophyll-degrading enzymes, as seen in this work. Ethylene is a well-known plant hormone that accelerates plant senescence [32]. In the present work, E-beam elicited ethylene production immediately after treatment, and the production was strongly suppressed at the end of storage, leading to a delay in chlorophyll degradation. Thus, low ethylene production in E-beam-treated fruit may cause a delay in chlorophyll degradation.

It is known that ROS is generally formed by the respiratory process of living cells. The plant's mitochondrial respiratory electron transport chain generates $\mathrm{O}^{-}{ }_{2}$ as a byproduct during energy metabolism in complex I and complex III [43, 44]. The $\mathrm{O}^{-\cdot}{ }_{2}$ is converted to $\mathrm{H}_{2} \mathrm{O}_{2}$ by SOD in the chloroplasts, peroxisomes, and mitochondria $[45,46]$. Afterward, $\mathrm{H}_{2} \mathrm{O}_{2}$ combines with the reduced transition metal ions such as $\mathrm{Fe}^{2+}$ or $\mathrm{Cu}^{+}$to generate $\mathrm{OH}^{-\cdot}$ via the Fenton and Haber-Weiss reaction [47]. Tahergorabi et al. [48] also demonstrated that ROS can generate in plants by water radiolysis under E-beam ionizing irradiation. Our experiment shows that E-beam treatment triggers the increase of $\mathrm{H}_{2} \mathrm{O}_{2}$ and $\mathrm{O}^{-}{ }_{2}$ immediately after treatment (day 0 ), which then gradually decreases throughout storage. Therefore, an increase of $\mathrm{H}_{2} \mathrm{O}_{2}$ and $\mathrm{O}^{-}{ }_{2}$ on day 0 may be caused by high respiratory and water radiolysis process. However, previous studies report that treatments of $\operatorname{ROS}\left(\mathrm{O}^{-}{ }_{2}, \mathrm{H}_{2} \mathrm{O}_{2}\right.$, and hydroxy radical $\left.\left(\mathrm{OH}^{-} \cdot\right)\right)$ in higher plants are a cause of chlorophyll degradation due to the chlorophyll phytyl chain getting oxidized to form isophytol $[15,16]$. Therefore, high chlorophyll degradation in E-beam-treated 

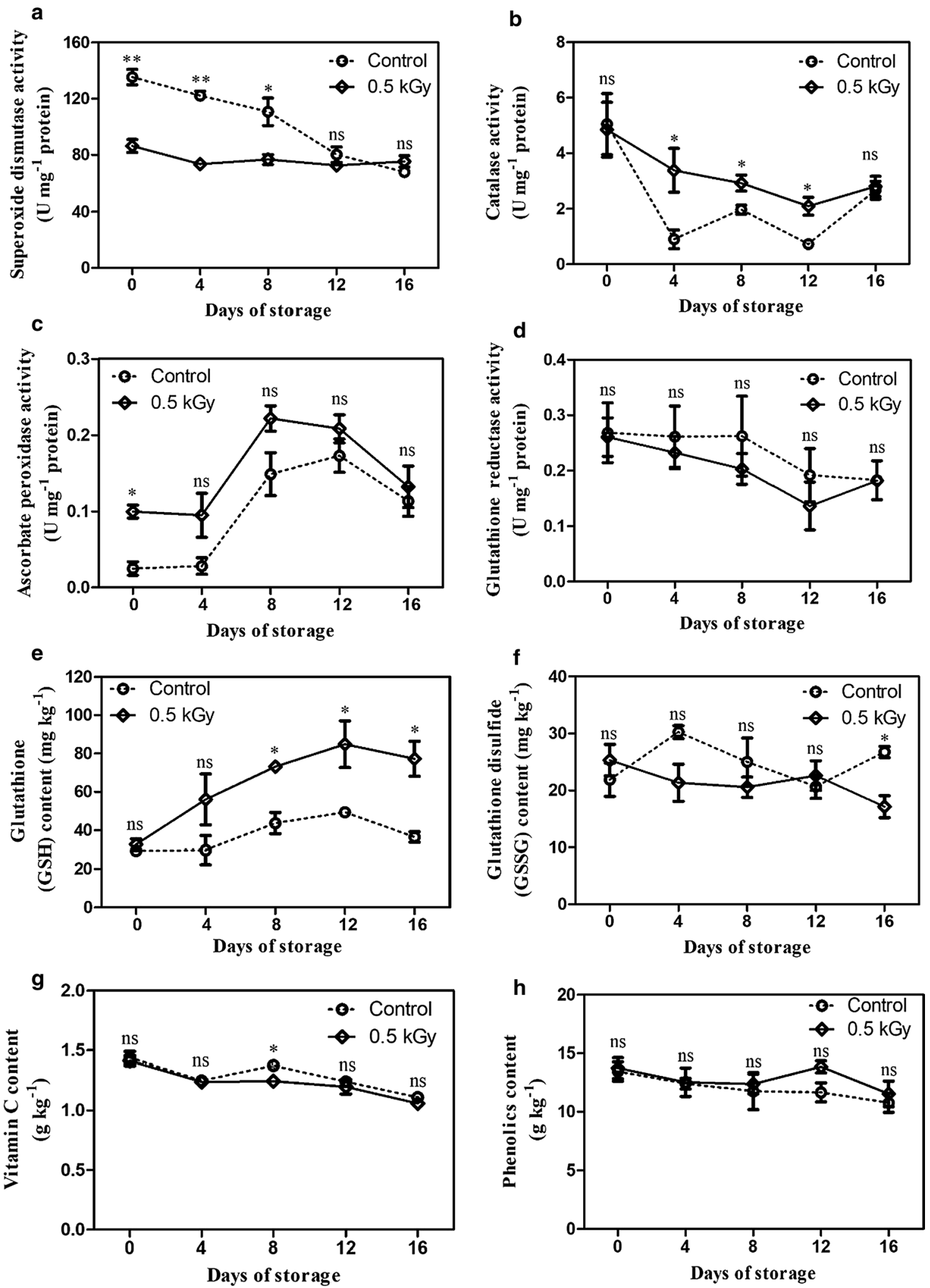

Fig. 5 Superoxide dismutase (a), catalase (b), ascorbate peroxidase (c), glutathione reductase (d), glutathione content (e), glutathione disulfide (f), vitamin C content ( $\mathbf{g}$ ) and phenolic content of mangoes after treatment with E-beam at a dose of 0 (control) and $0.5 \mathrm{kGy}$, and then stored at $13^{\circ} \mathrm{C}$ for 16 days. The data are expressed as mean \pm standard error. Asterisks $\left(^{*}\right)$ indicate significant differences between the two treatments during storage (t-test; ${ }^{*} P<0.05,{ }^{* *} \mathrm{P}<0.01$, ns not significant) 
fruit on day 4 can be assumed to have been caused by high $\mathrm{H}_{2} \mathrm{O}_{2}$ and $\mathrm{O}^{-}{ }_{2}$ production, and the low chlorophyll degradation from day 8 until the end of storage is related with the low content of $\mathrm{H}_{2} \mathrm{O}_{2}$ and $\mathrm{O}^{-} \cdot{ }_{2}$.

The antioxidant system is known to play an important role in delaying chlorophyll degradation and plant senescence [49-51]. E-beam irradiation also affects the antioxidant capacity that participates in scavenging ROS in plants. The present study shows that E-beam irradiation suppresses SOD activity. Similarly, results of previous studies show that ionizing beta-irradiation or gamma irradiation retards SOD activity in mandarins [52], apricots [53], pepper [54], and Zizania latifolia [55]. The activities of CAT and APX in E-beam-treated fruit tended to increase during storage as compared to the control fruits in the present study. These results are in agreement with those of Zhang et al. [52], Duan et al. [56], Hong et al. [57], and El-Beltagi et al. [58], who respectively reported that ionizing irradiation triggers an increase in CAT and APX activities in mandarin, wheat, and rosemary.

Vitamin $\mathrm{C}$ is an antioxidant compound that preserves the quality and phytonutrient of a fruit, whereas GSH plays an important role in detoxification, antioxidant defense, thiol status maintenance, and cell proliferation modulation [59]. Both vitamin $\mathrm{C}$ and GSH are associated with the ascorbate-glutathione cycle, which plays a crucial role in protecting plant cells in response to stress [60]. Our results show that the vitamin C content decrease in both the E-beam-treated and non-treated fruits without any significant differences. In contrast, the GSH content increase in a similar pattern in both the groups from days 0 to 12 , with a slight decrease toward the end of the storage period. Similar results were demonstrated by Kim and Yook [61] and Maraei and Elsawy [62], indicating that vitamin $C$ content in harvested kiwis and strawberries does not get affected by gamma irradiation. Further, Erkan et al. [63] reported that UV irradiation induces an increase in GSH in strawberries. GR is an ubiquitous NADPH-dependent enzyme that converts GSSG to GSH in the ascorbate-glutathione cycle [60]. The present results indicate that E-beam treatment does not affect GR activity during storage. Moreover, the present research shows that E-beam treatment does not affect phenolic compounds. These results suggest that E-beam has the potential to apply on mango fruits and other fruits for delaying ripening and senescence such as our recent research in lime fruit [64]. It can be used as the optional treatment of ionizing gamma ray. Because the limits of gamma irradiation are high cost, difficult to operation as compared with E-beam irradiation. Since the radioactive isotopes $\left({ }^{60} \mathrm{Co}\right.$, harmful) is required to generate gamma ray where E-beam uses the electricity as the energy source to generate E-beam [65] which it is much safer than using radioactive nuclides. However, the basic research information of E-beam treatment for mango industry still limits. Its application for controlling physiochemical changes, insect infestation and postharvest diseases are required in further study.

\section{Supplementary Information}

The online version contains supplementary material available at https://doi. org/10.1186/s13765-021-00592-8.

Additional file 1: Figure S1. E-beam irradiator that was used in this experiment. Figure S2. The illustration of dosimeters set up for dose mapping of mangoes in an E-beam process. Figure S3. Video shows the loading process of mango for E-beam irradiation. Figure S4. Alanine pellet dosimeters ( $\mathrm{A}$ and $\mathrm{B})$ and electron spin resonance spectroscopy (E-scan ${ }^{\mathrm{TM}}$ ) for alanine dosimeter reader $(C)$ that were used in this experiment.

\section{Acknowledgements}

The authors express their gratitude to Ms. Nuatawan Thamrongsiripak, Mr. Paiboon Kovitchaoenkul, and Ms. Jaruratana Eamsiri from the Thailand Institute of Nuclear Technology (TINT), Nakhon Nayok province, for facilitating E-beam irradiation for this study.

\section{Authors' contributions}

TTN performed experiments and wrote the manuscript. PJ designed the project and wrote the manuscript. AU, NL, VS and MK provided the discussion. All authors read and approved the final manuscript.

\section{Funding}

This research was supported by the Petch Pra Jom Klao Ph.D.'s Degree Research Scholarship from King Mongkut's University of Technology Thonburi, Bangkok, Thailand (Agreement No. 24/2560) and Thailand Research Fund and United Graduated School of Agricultural Science (UGSAS), Gifu University, for their help with some of the research materials and equipment.

\section{Availability of data and materials}

The datasets used and/or analysed during the current study are available from the corresponding author on reasonable request.

\section{Competing interests}

The authors declare that they have no competing interests.

\section{Author details}

1 Division of Postharvest Technology, School of Bioresources and Technology, King Mongkut's University of Technology Thonburi, Bangkok 10140, Thailand. 2 Postharvest Technology Innovation Center, Commission of Higher Education, Bangkok 10400, Thailand. ${ }^{3}$ Division of Biochemical Technology, School of Bioresources and Technology, King Mongkut's University of Technology Thonburi, Bangkok 10140, Thailand. ${ }^{4}$ Department of Bioresource Science, Faculty of Agriculture, Shizuoka University, Shizuoka 422-8529, Japan.

Received: 12 October 2020 Accepted: 13 January 2021

Published online: 03 February 2021

\section{References}

1. Ulloa JA, Guatemala GM, Arriola E, Escalona HB, Díaz L (2009) Estimation of the diffusivities of sodium chloride, potassium sorbate and sodium bisulphite in mango slices processed by hurdle technology. J Food Eng 91(2):211-216. https://doi.org/10.1016/j.ffoodeng.2008.08.032

2. Zheng M, Shi J, Shi J, Wang Q, Li Y (2013) Antimicrobial effects of volatiles produced by two antagonistic Bacillus strains on the anthracnose pathogen in postharvest mangos. Biol Control 65(2):200-206. https://doi. org/10.1016/j.biocontrol.2013.02.004 
3. Kim Y, Lounds-Singleton AJ, Talcott ST (2009) Antioxidant phytochemical and quality changes associated with hot water immersion treatment of mangoes (Mangifera indica L.). Food Chem 115(3):989-993. https://doi. org/10.1016/j.foodchem.2009.01.019

4. Narayana CK, Pal RK, Roy, SK (1996) Effect of pre-storage treatments and temperature regimes on shelf-life and respiratory behaviour of ripe Baneshan mango. J Food Sci Technol 33(1):79-82. https://www.semanticsc holar.org/paper/Effect-of-pre-storage-treatments-and-temperature-onNarayana-Pal/72ac164aad6f37c6e78198dbe81fb8d238ed5cd. Accessed 19 Nov 2019

5. Mercadante AZ, Rodriguez-amaya DB (1998) Effects of ripening, cultivar differences, and processing on the carotenoid composition of mango. $J$ Agric Food Chem 8561(97):128-130. https://doi.org/10.1021/jf9702860

6. Roca M, Chen K, Pérez-Gálvez A (2016) Handbook of natural pigments in food and beverage. Elsevier Ltd, Saint Louis, pp 125-158

7. Matile P, Schellenberg M, Vicentini F (1997) Localization of chlorophyllase in the chloroplast envelope. Planta 201(1):96-99. https://doi.org/10.1007/ BF01258685

8. Harpaz-Saad S, Azoulay T, Arazi T, Ben-Yaakov E, Mett A, Shiboleth YM, Hörtensteiner S, Gidoni D, Gal-On A, Goldschmidt EE, Eyal Y (2007) Chlorophyllase is a rate-limiting enzyme in chlorophyll catabolism and is posttranslationally regulated. Plant Cell 19(3):1007-1022. https://doi. org/10.1105/tpc.107.050633

9. Büchert AM, Civello PM, Martínez GA (2011) Characterization of Mgdechelating substance in senescent and pre-senescent Arabidopsis thaliana leaves. Biol Plant 55(1):75-82. https://doi.org/10.1007/s1053 5-011-0010-1

10. Shioi Y, Tatsumi Y, Shimokawa K (1991) Enzymatic degradation of chlorophyll in Chenopodium album. Plant Cell Physiol 32(1):87-93. https://doi. org/10.1093/oxfordjournals.pcp.a078056

11. Takamiya K, Tsuchiya T, Ohta H (2000) Degradation pathway(s) of chlorophyll: what has gene cloning revealed? Trends Plant Sci 5(10):426-431. https://doi.org/10.1016/S1360-1385(00)01735-0

12. Matile P, Schellenberg M, Peisker C (1992) Production and release of a chlorophyll catabolite in isolated senescent chloroplasts. Planta 187(2):230-235. https://doi.org/10.1007/BF00201944

13. Yamauchi N, Funamoto Y, Shigyo M (2004) Peroxidase-mediated chlorophyll degradation in horticultural crops. Phytochem 3:221-228. https:// doi.org/10.1023/B:PHYT.0000047796.98784.06

14. Gandul-rojas B, Roca M, Mínguez-mosquera MI (2004) Chlorophyll and carotenoid degradation mediated by thylakoid-associated peroxidative activity in olives (Olea europaea) cv. Hojiblanca. J Plant Physiol 161:499-507

15. Rontani JF, Cuny P, Grossi V (1996) Photodegradation of chlorophyll phytyl chain in senescent leaves of higher plants. Phytochem 42(2):347-351. https://doi.org/10.1016/0031-9422(95)00872-1

16. Rontani J, Galeron M (2016) Autoxidation of chlorophyll phytyl side chain in senescent phototrophic organisms: a potential source of isophytol in the environment. Org Geochem 97:35-40. https://doi.org/10.1016/j. orggeochem.2016.03.008

17. Barkai-Golan R, Follett PA (2017) Irradiation for quality improvement, microbial safety, and phytosanitation of fresh produce. Elsevier Inc., London

18. Hussain PR, Rather SA, Suradkar PP, Ayob O (2019) Gamma irradiation treatment of quince fruit (Cydonia oblonga Mill): effect on post-harvest retention of storage quality and inhibition of fungal decay. J Radiat Res Appl Sci 12(1):118-131. https://doi.org/10.1080/16878507.2019.1618588

19. Kumar M, Ahuja S, Dahuja A, Kumar R, Singh B (2014) Gamma radiation protects fruit quality in tomato by inhibiting the production of reactive oxygen species (ROS) and ethylene. J Radioanal Nucl Chem 301(3):871880. https://doi.org/10.1007/s10967-014-3234-7

20. Hussain PR, Dar MA, Wani AM (2013) Impact of radiation processing on quality during storage and post-refrigeration decay of plum (Prunus domestica L.) cv. Santaroza. Radiat Phys Chem 85:234-242. https://doi. org/10.1016/j.radphyschem.2013.01.020

21. Wani AM, Hussain PR, Meena RS, Dar MA (2008) Effect of gamma-irradiation and refrigerated storage on the improvement of quality and shelf life of pear (Pyrus communis L., cv. Bartlett/William). Radiat Phys Chem 77(8):983-989. https://doi.org/10.1016/j.radphyschem.2008.04.005

22. Hussain PR, Suradkar P, Javaid S, Akram H, Parvez S (2016) Influence of postharvest gamma irradiation treatment on the content of bioactive compounds and antioxidant activity of fenugreek (Trigonella foenum-graceum L.) and spinach (Spinacia oleracea L.) leaves. Innov Food Sci Emerg Technol 33:268-281. https://doi.org/10.1016/j.jfset.2015.11.017

23. Truc NT, Uthairatanakij A, Srilaong V, Laohakunjit N, Jitareerat P (2021) Effect of electron beam radiation on disease resistance and quality of harvested mangoes. Radiat Phys Chem 180:109289. https://doi. org/10.1016/j.radphyschem.2020.109289

24. IAEA-TECDOC-1070 (1998) Techniques for high dose dosimetry in industry, agriculture and medicine, in session 6: process validation. In: Proceedings of a symposium. Vienna, pp 229-271. https://www.iaea.org/ publications/5366/techniques-for-high-dose-dosimetry-in-industry-agric ulture-and-medicine-proceedings-of-a-symposium-held-in-vienna-9-13november-1998. Accessed 19 Nov 2019

25. Moran R (1982) Formulae for determination of chlorophyllous pigments extracted with N,N-dimethylformamide. Plant Physiol 69(6):1376-1381. https://doi.org/10.1104/pp.69.6.1376

26. Aiamla-or S, Nakajima T, Shigyo M, Yamauchi N (2012) Pheophytinase activity and gene expression of chlorophyll-degrading enzymes relating to UV-B treatment in postharvest broccoli (Brassica oleracea $\mathrm{L}$. Italica Group) florets. Postharvest Biol Technol 63(1):60-66. https://doi. org/10.1016/j.postharvbio.2011.08.003

27. Aiamla-or S, Kaewsuksaeng S, Shigyo M, Yamauchi N (2010) Impact of UV-B irradiation on chlorophyll degradation and chlorophyll-degrading enzyme activities in stored broccoli (Brassica oleracea L. Italica Group) florets. Food Chem 120(3):645-651. https://doi.org/10.1016/j.foodc hem.2009.10.056

28. Vicentini F, Iten F, Matile P (1995) Development of an assay for Mg-dechelatase of oilseed rape cotyledons, using chlorophyllin as the substrate. Physiol Plant 94(1):57-63. https://doi.org/10.1111/j.1399-3054.1995.tb007 84.x

29. Kaewsuksaeng S, Urano Y, Aiamla-or S, Shigyo M, Yamauchi N (2011) Effect of UV-B irradiation on chlorophyll-degrading enzyme activities and postharvest quality in stored lime (Citrus latifolia Tan.) fruit. Postharvest Biol Technol 61(2-3):124-130. https://doi.org/10.1016/j.postharvbi 0.2011 .02 .014

30. Bradford MM (1976) A rapid and sensitive method for the quantitation microgram quantities of protein utilizing the principle of protein-dye binding. Anal Biochem 254:248-254. http://www.rotoplast.com.co/siste ma-septico-domiciliario/

31. Yamauchi N, Xia X, Hashinaga F (1997) Involvement of flavonoid oxidation with chlorophyll degradation by peroxidase in wase Satsuma mandarin fruits. J Jpn Soc Hortic Sci 66(2):283-288. https://doi.org/10.2503/ jjshs.66.283

32. Costa L, Civello PM, Chaves AR, Mart GA (2005) Effect of ethephon and 6-benzylaminopurine on chlorophyll degrading enzymes and a peroxidase-linked chlorophyll bleaching during post-harvest senescence of broccoli (Brassica oleracea L.) at $20^{\circ} \mathrm{C}$. Postharvest Biol Technol 35:191-199. https://doi.org/10.1016/j.postharvbio.2004.07.007

33. Wu Y, Duan X, Jing G, Ouyang Q, Tao N (2017) Cinnamaldehyde inhibits the mycelial growth of Geotrichum citri-aurantii and induces defense responses against sour rot in citrus fruit. Postharvest Biol Technol 129:23-28. https://doi.org/10.1016/j.postharvbio.2017.03.004

34. Elstner EF, Heupel A (1976) Inhibition of nitrite formation from hydroxylammoniumchloride: a simple assay for superoxide dismutase. Anal Biochem 70(2):616-620. https://doi.org/10.1016/0003-2697(76)90488-7

35. Wierzbicka GT, Hagen TM, Tones DP (1989) Glutathione in food. J Food Compos Anal 2(4):327-337. https://doi.org/10.1016/0889-1575(89)90004

36. Griffth OW (1980) Determination of glutathione and glutathione disulfide. Anal Biochem 106:207-212. https://doi.org/10.1248/bpb.33.556

37. Ribeiro SMR, Barbosa LCA, Queiroz JH, Knödler M, Schieber A (2008) Phenolic compounds and antioxidant capacity of Brazilian mango (Mangifera indica L.) varieties. Food Chem 110(3):620-626. https://doi.org/10.1016/j. foodchem.2008.02.067

38. Singleton VL, Orthofer R, Lamuela-Ravent RM (1998) Analysis of total phenols and other oxidation substrates and antioxidants by means of folin-ciocalteu reagent. Methods Enzymol 299:152-178. https://doi. org/10.1016/S0076-6879(99)99017-1

39. Roe JH, Mills MB, Oesterling MJ, Damron CM (1948) The determination of diketo L-gulonic acid, dehydro-L-ascorbic acid, and L-ascorbic acid in 
the same tissue extract by the 2,4-dinitrophenylhydrazine method. J Biol Chem 174(1):201-208

40. Noctor G, Mhamdi A, Foyer CH (2016) Oxidative stress and antioxidative systems: recipes for successful data collection and interpretation. Plant Cell Environ 39(5):1140-1160. https://doi.org/10.1111/pce.12726

41. Rao MV, Paliyath G, Ormrod P (1996) Ultraviolet-B and ozone-induced biochemical changes in antioxidant enzymes of Arabidopsis thaliana. Plant Physiol 110:125-136. https://doi.org/10.1104/pp.110.1.125

42. Medlicott AP, Bhogal M, Reynolds SB (1986) Changes in peel pigmentation during ripening of mango fruit. Ann Appl Biol 109:651-656

43. Huang S, Aken OV, Schwarzländer M, Belt K, Miller AH (2016) The roles of mitochondrial reactive oxygen species in cellular signalling and stress response in plants. Plant Physiol 171(3):1551-1559. https://doi. org/10.1104/pp.16.00166

44. Rhoads DM, Umbach AL, Subbaiah CC, Siedow JN (2006) Mitochondrial reactive oxygen species. Contribution to oxidative stress and interorganellar signaling. Plant Physiol 141(2):357-366. https://doi.org/10.1104/ pp.106.079129

45. Noctor G, Reichheld JP, Foyer CH (2018) ROS-related redox regulation and signaling in plants. Semin Cell Dev Biol 80:3-12. https://doi.org/10.1016/j. semcdb.2017.07.013

46. Mittler R (2002) Oxidative stress, antioxidants and stress tolerance. Trends Plant Sci 7(9):405-410. https://doi.org/10.1016/S1360-1385(02)02312-9

47. Fry SC (1998) Oxidative scission of plant cell wall polysaccharides by ascorbate-induced hydroxyl radicals. Biochem J 332(2):507-515. https:// doi.org/10.1042/bj3320507

48. Tahergorabi R, Matak KE, Jaczynski J (2012) Application of electron beam to inactivate Salmonella in food: recent developments. Food Res Int 45(2):685-694. https://doi.org/10.1016/j.foodres.2011.02.003

49. Jincy M, Djanaguiraman M, Jeyakumar P, Subramanian KS, Jayasankar S, Paliyath G (2017) Inhibition of phospholipase D enzyme activity through hexanal leads to delayed mango (Mangifera indica L.) fruit ripening through changes in oxidants and antioxidant enzymes activity. Sci Hortic 218:316-325. https://doi.org/10.1016/j.scienta.2017.02.026

50. Zhu L, Wang W, Shi J, Zhang W, Shen Y, Du H, Wu S (2014) Hydrogen sulfide extends the postharvest life and enhances antioxidant activity of kiwifruit during storage. J Sci Food Agric 94(13):2699-2704. https://doi. org/10.1002/jsfa.6613

51. Yahia EM, Soto-Zamora G, Brecht JK, Gardea A (2007) Postharvest hot air treatment effects on the antioxidant system in stored maturegreen tomatoes. Postharvest Biol Technol 44(2):107-115. https://doi. org/10.1016/j.postharvbio.2006.11.017

52. Zhang K, Deng Y, Fu H, Weng Q (2014) Effects of Co-60 gamma-irradiation and refrigerated storage on the quality of Shatang mandarin. Food Sci Hum Wellness 3(1):9-15. https://doi.org/10.1016/j.fshw.2014.01.002

53. Egea Ml, Sánchez-Bel P, Martínez-Madrid MC, Flores FB, Romojaro F (2007) The effect of beta ionization on the antioxidant potential of "Búlida" apricot and its relationship with quality. Postharvest Biol Technol 46(1):63-70. https://doi.org/10.1016/j.postharvbio.2007.04.002

54. Martínez-Solano JR, Sánchez-Bel P, Egea I, Olmos E, Hellin E, Romojaro F (2005) Electron beam ionization induced oxidative enzymatic activities in pepper (Capsicum annuum L.), associated with ultrastructure cellular damages. J Agric Food Chem 53(22):8593-8599. https://doi.org/10.1021/ jf050994i

55. Fan J, Shi M, Huang JZ, Xu J, Wang ZD, Guo DP (2014) Regulation of photosynthetic performance and antioxidant capacity by $60 \mathrm{Co}$-irradiation in Zizania latifolia plants. J Environ Radioact 129:33-42. https://doi. org/10.1016/j.jenvrad.2013.11.013

56. Duan Z, Xing Z, Shao Y, Zhao X (2010) Effect of electron beam irradiation on postharvest quality and selected enzyme activities of the white button mushroom, Agaricus bisporus. J Agric Food Chem 58(17):9617-9621. https://doi.org/10.1021/jf101852e

57. Hong MJ, Kim JB, Yoon YH, Kim SH, Ahn JW, Jeong IY, Kang SW, Seo SW, Kim DS (2014) The effects of chronic gamma irradiation on oxidative stress response and the expression of anthocyanin biosynthesis-related genes in wheat (Triticum aestivum). Int J Radiat Biol 90(12):1218-1228. https://doi.org/10.3109/09553002.2014.934930

58. El-Beltagi HS, Ahmed OK, El-Desouky W (2011) Effect of low doses $\gamma$-irradiation on oxidative stress and secondary metabolites production of rosemary (Rosmarinus officinalis L.) callus culture. Radiat Phys Chem 80:968-976. https://doi.org/10.1016/j.radphyschem.2011.05.002

59. Lu SC (2013) Glutathione synthesis. Biochim Biophys Acta-Gen Subj 1830(5):3143-3153. https://doi.org/10.1016/j.bbagen.2012.09.008

60. Noctor G, Arisi ACM, Jouanin L, Kunert KJ, Rennenberg H, Foyer CH (1998) Glutathione: biosynthesis, metabolism and relationship to stress tolerance explored in transformed plants. J Exp Bot 49(321):623-647. https:// doi.org/10.1093/jxb/49.321.623

61. Kim KH, Yook HS (2009) Effect of gamma irradiation on quality of kiwifruit (Actinidia deliciosa var. deliciosa cv. Hayward). Radiat Phys Chem 78(6):414-421. https://doi.org/10.1016/.j.radphyschem.2009.03.007

62. Maraei RW, Elsawy KM (2017) Chemical quality and nutrient composition of strawberry fruits treated by $Y$-irradiation. J Radiat Res Appl Sci 10:80-87

63. Erkan M, Wang SY, Wang CY (2008) Effect of UV treatment on antioxidant capacity, antioxidant enzyme activity and decay in strawberry fruit. Postharvest Biol Technol 48:163-171. https://doi.org/10.1016/j.postharvbi 0.2007 .09 .028

64. Pongsri R, Aiamla-or S, Srilaong V, Uthairatanakij A, Jitareerat P (2021) Impact of electron-beam irradiation combined with shellac coating on the suppression of chlorophyll degradation and water loss of lime fruit during storage. Postharvest Biol Technol 172:111364. https://doi. org/10.1016/j.postharvbio.2020.111364

65. Kilcast D (1995) Food irradiation: current problems and future potential. Int Biodeterior Biodegrad 36:279-296. https://doi.org/10.1016/09648305(95)00071-2

\section{Publisher's Note}

Springer Nature remains neutral with regard to jurisdictional claims in published maps and institutional affiliations.

\section{Submit your manuscript to a SpringerOpen ${ }^{\circ}$ journal and benefit from:}

- Convenient online submission

- Rigorous peer review

- Open access: articles freely available online

- High visibility within the field

- Retaining the copyright to your article

Submit your next manuscript at $\boldsymbol{\nabla}$ springeropen.com 